\title{
20. Yüzyıl Türk Mimarlığının Nitelikli Örnekleri olarak Etimesgut ve T.B.M.M. Camileri'nin Çevre Estetiği Temelinde Okunması
}

\author{
An Environmental Aesthetic Reading of the Etimesgut and T.B.M.M. Mosques \\ as Qualified Examples of $20^{\text {th }}$ Century Turkish Architecture
}

\begin{abstract}
Kemal Reha KAVAS * Ayşe ŞEKERCI ${ }^{* *}$

Öz: 20. Yüzyılda Türkiye'de üretilen camilerin çoğunluğunun tarihsel biçimlerin gelişigüzel tekrarları olduğu ve özgün mimari tasarım niteliği üretemediği sıklıkla ifade edilmektedir. "Estetik", cami tasarımında niteliğin tartışılması için önemli bir anahtar sözcüktür çünkü etimolojik kökeni uyarınca duyusal bilginin bilimi olarak anlaşıldığında, mimarlığa yüzeysel açıklamaların ötesinde özgün bir boyut kazandırabilir. Duyusal deneyime sahne olan mimarlığın daima estetiğin konusu olduğuna dair farkındalık tasarımın niteliğini geliştirir. $\mathrm{Bu}$ yolla ibadet yapıları biçimsel tekrarın ötesine geçerek kullanıcının duyusal farkındalıklarına hitap edebilir ve mekâna duyusal ve bedensel katılım ile varoluşsal anlamlar üretilebilir. Bu çalışmada Cengiz Bektaş (d.1934) ve Behruz Çinici (1932-2011) - Can Çinici (d.1962) tarafından tasarlanarak 20. yüzyıl Türk mimarlık literatüründe yer edinen Etimesgut (Ankara, 1967) ve T.B.M.M. (Ankara, 1989) camileri çevre estetiği kuramı çerçevesinde yeniden okunmakta ve özgün tasarım nitelikleri incelenmektedir.
\end{abstract}

Anahtar sözcükler: Estetik, Çevre, Mimarlık, Cami, İbadet, Türkiye

Abstract: It is frequently stated that the majority of the mosques built in Turkey during the $20^{\text {th }}$ century reflect uncritical repetitions of historical forms, thus cannot produce original architectural design quality. "Aesthetics" is an important keyword for the discussion of the problem of quality in the design of mosques because when "aesthetics" is regarded, in tune with its etymological roots, as the science of sensual knowledge, it can produce spatial originality by going beyond superficial explanations. Consciousness of the fact that architecture, which is a stage of sensual experience, is always an issue of aesthetics has a significant effect on design quality. In this way, spaces of worship may address sensual consciousness of the users and establish existential meanings through sensual and bodily engagement. This study rereads the Etimesgut (Ankara, 1967) and T.B.M.M. (Turkish Grand National Assembly) (Ankara, 1989) Mosques designed by Cengiz Bektaş (b.1934) and Behruz Çinici (1932-2011) - Can Çinici (b.1962) within the framework of environmental aesthetics. These significant buildings of 20th century Turkish architecture are analyzed through their original qualities of design.

Keywords: Aesthetics, Environment, Architecture, Mosque, Worship, Turkey

\section{Giriş}

Cengiz Bektaş'ın (d. 1934) yedek subay olarak askerlik görevini yaptığı sırada tasarlayarak askeri birlikteki personel imkânları içerisinde uygulamasını da yönettiği Etimesgut Camii (Ankara, 1967), Türkiye'de Cumhuriyet döneminde tarihsel biçim referanslarından sıyrılarak özgün bir tasarım sürecini temsil eden ilk cami örneklerden biri olarak konumlandırılmaktadır

\footnotetext{
* Prof. Dr., Akdeniz Üniversitesi, Mimarlık Fakültesi, Mimarlık Bölümü, Antalya. kemalkavas@akdeniz.edu.tr, https://orcid.org/0000-0002-2577-1034

** Öğr. Gör., Akdeniz Üniversitesi, Mimarlık Fakültesi, Mimarlık Bölümü, Antalya. aysesekerci@akdeniz.edu.tr, https://orcid.org/0000-0002-7393-4010
} 
(Bektaş 1973). Üçgen birimler ile örülü bir ızgara sistemine oturtulan ve farklı boyutlar ile iç içe geçen altıgenlerden oluşan planda izlenen açıklıklar üçüncü boyutta düşey yarıklar olarak döşemeden çatıya süreklilik göstermektedir. Bu yarıklar, tarihsel kalıpların dışına çıkan mekânsal etkiler üreterek hem iç mekândaki temel 1şık - gölge kontrastlarını oluşturmuş hem de kubbe içermeyen kütlesel plastiğin belirleyici öğeleri olmuştur (Fig. 1). Yapıda farklı namaz vakitlerindeki farklı ışı etkileri ile kullanıcıya çevresel farkındalık oluşturma imkânı sunulmuş ve iç mekâna sızan 1şık sonsuzluk kavramının bir ifadesi olarak yorumlanmıştır (Url 2).

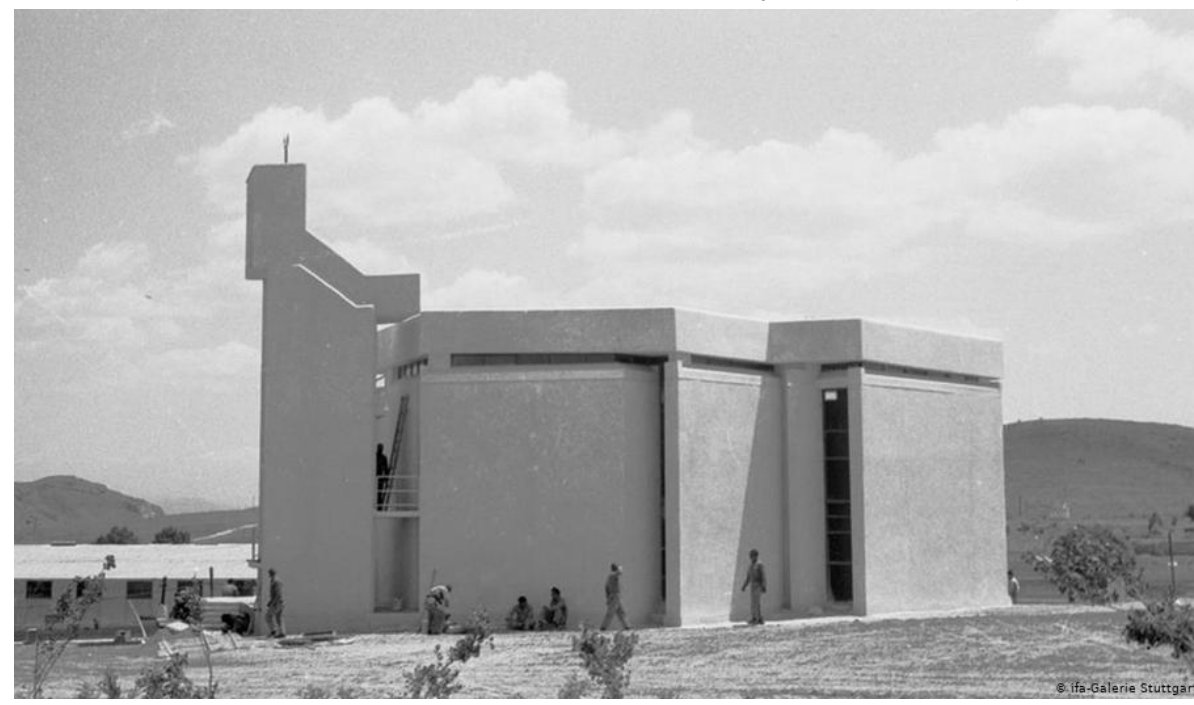

Fig. 1. Etimesgut Cami (Url 1)

Türkiye'de Cumhuriyet döneminde üretilen cami tasarımları bağlamında kalıplaşmış biçimsel kabullere eleştirel açıdan yaklaşarak özgünlük iddiası geliştiren en nitelikli örneklerden biri de Behruz Çinici (1932-2011) ve Can Çinici'nin (d. 1962) tasarladığı TBMM Camisi (Ankara, 1989) olarak kabul edilmektedir (Kuban 2013). İçinde yer aldığı TBMM yerleşkesinde eğimli bir araziye uyum sağlayarak konumlanan bu yapı da camiye ilişkin gelişmiş biçimsel kalıpları sorgulamaktadır (Fig. 2). Özgün mekânsal öneriler tamamen şeffaflaşarak cennet imgesini temsil eden gömük bir bahçe ile görsel bağlantı kuran mihrap duvarı, kubbenin anılarını hatırlatan fakat çağdaş malzemenin doğasına uyarak biçimlenen kademeli üst örtü ve minarenin dikeyliğini temsil eden selvi ağacında en belirgin ifadelerini bulmaktadır. Özellikle mihrap duvarının tamamen şeffaflaşması ile özgünlügünü ortaya koyan tasarım 20. yüzyıl Türkiye mimarlık tarihi kanonunun belirgin bir öğesi haline gelmiştir (Hasol 2017).

Etimesgut ve T.B.M.M. camilerinin 20. yüzyıl Türk mimarlığı bağlamında elde ettiği bu konumlar her iki yapının da özgün tasarım yaklaşımlarının çok ender görüldüğü bir işlevsel programa getirdikleri nitelikli mimari yorumlarından kaynaklanmaktadır. 20. yüzyılda Türkiye'de üretilen camilerin çoğunluğunun tarihsel biçimlerin gelişigüzel tekrarları olduğu ve çevresel olumsuzluklardan korunmayla sınırlandırılmış mekanik bir işlevselliği benimsediği, dolayısıyla mimari tasarım açısından özgün olmayan, niteliksiz sonuçlara yol açtıkları sıklıkla ifade edilmektedir (Eyüpgiller 2006; Güzer 2009; Kuban 2013). 


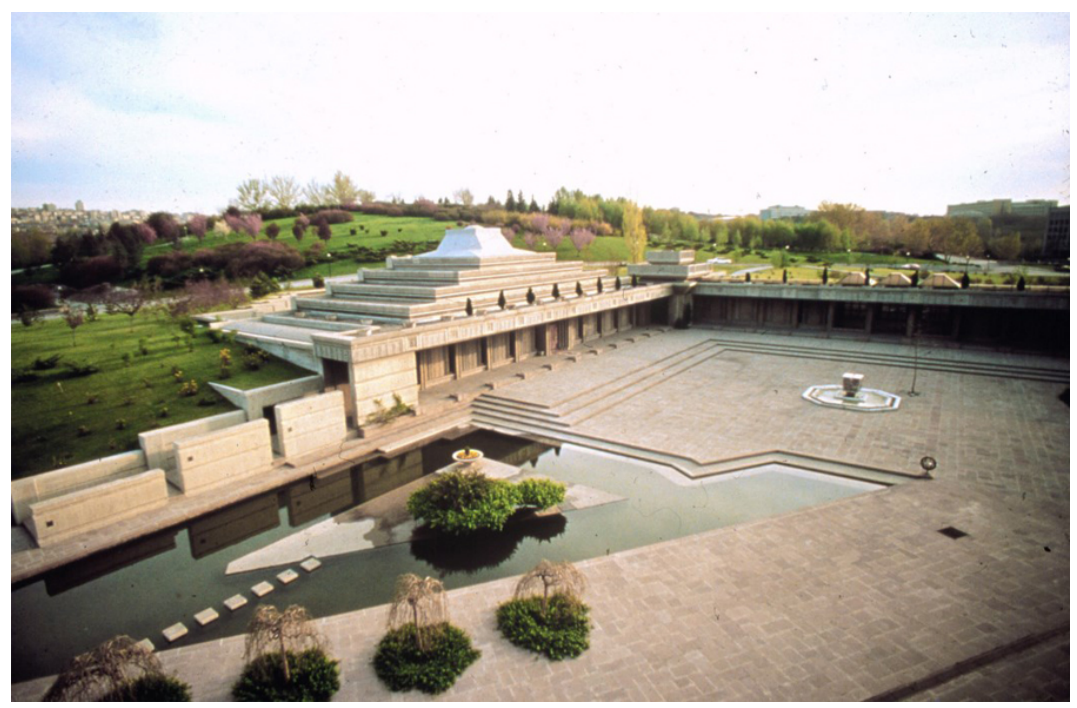

Fig. 2. T.B.M.M. Cami (Url3)

Değinilen iki yapının ise söz konusu bağlamda üretilen az sayıda nitelikli örneklerden olduğu kabul edilmektedir. Bu çalışma daha önce farklı kaynaklarda nitelikleri ayrı ayrı vurgulanan bu yapıların tasarım yaklaşımlarındaki örtüşmeleri ortak bir kuramsal çerçevede yeniden okumayı hedeflemektedir. Konuya giriş teşkil etmek üzere yukarıda verilen kısa tanımlamalar Etimesgut ve TBMM camilerinde geliştirilen farklı biçimsel yaklaşımlar ve plan kurgularına rağmen ortak bir düşünce zeminin varlığına işaret etmektedir. Her iki tasarımda da birçok 20. yüzyıl örneğinde sorgulanmadan kabul edilen tarihsel referanslı biçimsel kalıpların aşıldığı gözlenmektedir. Tasarımlarda kullanıcının estetik deneyiminin zenginleşmesi, mekâna duyusal ve bedensel katılımı ile varoluşu ve mekânı anlamlandırması için potansiyeller sunulmaktadır. $\mathrm{Bu}$ çalışmada Etimesgut ve T.B.M.M. camilerinin tanımlanan ortak düşünce zemini belirginleştirmek ve açıklamak için çevre estetiği kuramının kavramsal çerçevesine başvurulmaktadır.

\section{Çevre Estetiği Kuramı ve Mekânsal Deneyim}

Çevre estetiğini tanımlamadan önce "estetik" kavramının anlamını ortaya koymak gerekmektedir. "Estetik" Hellence'de "duyum, duyulur alg1" anlamina gelen "aisthesis" ve "duyu ile algılamak" anlamına gelen "aisthanesthai" kelimelerine dayandığından "duyusallığın sağladığ bilgi ile ilgili bir bilim" olarak düşünülmüştür (Tunalı 2003). Tunalı (2003) tıp terimi olarak kullanımda olan ve "duyarlığın yok edilmesi" anlamına gelen "anesthesi" sözcüğünün estetikteki duyusallık boyutunu örneklediğini ifade eder.

Tarihte belirli bir kültürel çevre içerisinde doğan kavramlar tarihsel süreç içerisinde farklı felsefi yaklaşımlar ve dönemsel ihtiyaçlar doğrultusunda kullanılarak etimolojik kökenlerindeki orijinal anlamlarından sapabilir. Bu durum "estetik" için de geçerlidir. Tıp terminolojisindeki "anesthesi" kavramı ile süreklilik gösteren estetiğe özgü kapsayıcı duyusallık boyutunun özellikle Batı Aydınlanması ve sonrasında sanat ve tasarım kuramından dışlandığı gözlenmektedir. Bu süreçte "estetik" insanoğlunun tüm çevresel verilere ilişkin duyumsallığından çok doğrudan sanat eserleri ile ilişkisi çerçevesine sınırlandırılmış, böylece birçok kaynakta "sanat felsefesi" ile eş anlamlı olarak kullanılmaya başlanmıştır (Huisman 1992; Bozkurt 1995). Estetiğin orijinal tanımı itibarı ile kapsamına giren ve toplumun genelini ilgilendiren birçok konu dışlanarak sadece sınırlı bir toplulukça üretilen, tartışılan ve gündelik yaşamdan yalıtılmış mekânlarda sergilenen güzel sanatlara ait yapıtlar üzerine odaklanılmıştır.

Çevre estetiği söz konusu anlayışa bir tepki olarak 20. yüzyılın son çeyreğine yaklaşırken ortaya çıkan, sosyal bilimler ile birlikte mimarlık ve sanat ile de yakından ilgili olan interdisipliner bir çalışma alanıdır ( $\operatorname{Url} 4$ ). Çevre estetiği, estetiğin konusunun müze mekânlarında 
günlük yaşamdan soyutlanmış durumdaki sanat yapıtları ile sınırlandırılmasına karşı çıkarak insanın gündelik yaşamında deneyimlediği doğal ve yapılı çevreleri de önemli inceleme konuları olarak estetiğin gündemine taşımıştır. Carlson'un (Url 4) ifadesi ile çevre estetiği, "dünyayı sadece belirli nesnelerden değil çevrelerden de müteşekkil olarak algılar”. Çevre estetiğinin gündelik yaşam çevresini kapsayıcı yaklaşımı 21. yüzyılda da gelişme göstermektedir (Url 4).

Çevre estetiği felsefi olarak Edmund Husserl (1859-1938) tarafindan ortaya atılan fenomenolojik düşünce üzerinde temellenmektedir. Bu düşünce, takipçilerinden Martin Heidegger'in (1889-1976) vurguladığı "dolaysız deneyim" kavramı üzerinden karakterize edilebilir. Heidegger çevrenin "entelektüel mesafeden" analiz edilmesine itiraz ederek çevreyle "dolaysız temas" kurulması gerektiğini savunur (Sharr 2013). İnsanın mekânsal deneyimini de yakından ilgilendiren bu yaklaşım mimari fenomenoloji (Norberg-Schulz 1980; Pallasmaa 2011) ve çevre estetiği kuramının (Berleant 2007) oluşumuna katkı sağlamıştır.

Çevre estetiğinin önemli kuramcılarından Arnold Berleant (d.1932) estetiği sanat felsefesi olarak sınırlandıran erken 20. yüzyıl yaklaşımını seyir estetiği olarak tanımlar ve bunun yerine çevre estetiğini yüklenim estetiği olarak önerir. Heidegger' in değindiği "entelektüel mesafeden analiz" seyir estetiği ile, "dolaysız deneyim" ise yüklenim estetiği ile doğrudan ilişkilidir. Berleant'ın çevrenin algılamasına en uygun kavram olarak nitelendirdiği "yüklenim estetiğinde", insan etkin katılımcı olarak rol alır ve çevreyi deneyimleyerek estetik algısı oluşur (Berleant 2007). Başka bir deyişle, tüm duyular dolayısıyla oluşan bedensel katılım ile estetik alg1 oluşur. Berleant'a (1997) göre insandan bağımsız olarak düşünülemeyen çevre "insan katkısı ve fiziksel konum arasındaki ahenkli birlikteliktir". Böylece çevreyle algısal - duyusal bir bütünleşme içeren her faaliyet estetiğin konusu haline gelir (Erzen 2006).

Çevre estetiğinin getirdiği kapsayıcı "estetik" tanımı kavramın Tunalı'nın (2003) değindiği orijinal anlama geri dönebilmeyi sağlar. Etimolojik kökenindeki duyusallık anlamı sebebiyle estetik, kullanıcının duyuları ile algıladığı ve anlamlandırdığı mimarlık alanı ile örtüşmektedir. $\mathrm{Bu}$ örtüşmenin farklı tarihsel aşamalarında mimarlık, kendisini üreten ve kullanıcısı olan insanın tüm duyularıyla katılım sağladığı mekânsal kurguların bütünü olarak tanımlanabilir. Böylece insanın yaşamını sürdürdüğü yapılı çevrede "algılayan özne" olarak algıladı̆̆ı nesneler ile kurduğu "ilişki örüntüsü” söz konusu olmakta ve bu örüntü mimarlık ile fenomenoloji arasında bağ kurarak "estetik yaşantıyı" üretmektedir (Aydınlı 2002). Mimari fenomenolojinin kurucularından Norberg-Schulz'a (1980) göre mimarlık insana ve çevreye kimlik ve aidiyet kazandıran ve bu değerleri sürdürülebilir k1lan somut ve bütüncül bir kültürel ifade biçimidir. Bu tanım "yüklenim estetiğinin" gereği olan bedensel katılım ile bir anlamlandırma ve aidiyet oluşturma sürecini bağdaştırır.

Günümüzde mimari pratik görsel temelli bir zihinsel rasyonalizasyon süreci doğrultusunda görmeyi, Berleant'in deyimiyle "seyir estetiğini”, önceleyerek diğer duyuların desteğiyle oluşan bedensel katılımı, yine Berleant'in kavramı ile, "yüklenim estetiğini" ikinci plana itmiştir. Buna rağmen insan doğasına uygun mekânsal algının syneasthesia kavramında, diğer bir ifade ile, duyuların sentezinde temellendiği unutulmamalıdır (Berleant 1997). Pallasmaa (2011) bu durumu, görme duyusunun tek başına dayattığ "odaklanmış görme" eylemi ile görme, duyma, koklama, tatma ve dokunmanın senteziyle oluşan "çevrel görme" eyleminin karşıtllı̆ı üzerinden açıklamaktadır. Bu bağlamda "çevrel görme" mekâna tek duyunun sınırlarını aşan bütüncül nitelikte bedensel katılım ve anlamlandırma sürecini karakterize eder.

\section{Çevre Estetiği Temelinde Bir Mimari Okuma Önerisi}

Çağımızda "estetik" kavramının anlamsal köklerinden kopartılarak "yüzeysel hoşluk" temelinde anlaşılması ve bu anlamsal sapmanın mimarlık disiplinine ve yapı pratiğine de sirayet etmesi mimari tasarımın bütünselliği ve niteliği açısından ciddi sorunlara yol açmaktadır (Kavas 2015). 
"Mimari konsept" tasarım sürecine baştan sona tutarlı bir rehberlik sağlayan kavramsal altyapı olarak anlaşılmak yerine işveren talepleri veya toplumsal beklentiler doğrultusunda yüzeylerin veya kütlelerin biçimlenmesine indirgenmektedir. Çağın inşai konvansiyonlarına uyan bir kaba yapının yüzeyleri üzerine işverenin taleplerine ve toplumsal konvansiyonlara göre değiştirilebilen kaplamaların veya biçimsel giydirmelerin uygulanması yapıyı ayakta tutan "inşai yapı" (constructional fabric) ile toplumsal bağlamda gösterge değeri taşıyan "temsili sahne tasarımı" (representative scenography) ikiliğini oluşturmaktadır (Frampton 1983).

$\mathrm{Bu}$ çalışmanın araştırma materyalini ilgilendirmekte olan 20. yüzyıl Türkiye camilerinin mimarlık literatürü dışında kalan örnekleri de sözü edilen ikiliğin somutlaşmaları olarak görülebilir. Bu örneklerde kubbeli örtü sistemleri çağdaş yapı teknolojisinde karşılığ 1 olmaksızın sadece toplumsal beklentiler dolayısıyla ve görsel mesaj veren gösterge değerleri ile kullanılmaya devam etmektedir. Tarihsel kent siluetleri içinde anlam üreten formlar bağlamlarından kopartılarak hiç bir sorgulamaya tabi tutulmadan çağdaş kentlerde tekrarlanmaktadır (Kuban 2013).

Buna karşın, kullanıcının dokunsal ve bedensel algısını ve mekana bu yönüyle katılımını dikkate alan mimari tasarım süreçleri yukarıda tanımlanan yaklaşımdan ayrışmaktadır. Mekânsal derinlikte ve üç boyutta üretilen gerçek "estetik" duyarlık tarih boyunca kullanıcının duyusal sentez yoluyla mekânı deneyimlemesini, bu deneyim üzerinden kendi var oluşunu anlamlandırmasını ve mekânsal aidiyet duygularını geliştirmesini sağlamıştır (Norberg-Schulz 1975). Çağımızda ise mimarlığın kullanıcı tarafından algısının görsel ve yüzeysel etkilere indirgendiği, bu durumun mimarlığın tarihsel zemini açısından hayati önem taşıyan anlam ve aidiyet kavrayışları açısından ciddi sorunlara yol açtığı görülmektedir (Norberg-Schulz 1980; Sharr 2013).

Pallasmaa'nın (2011) deyimi ile çağımızın dayattığı "odaklanmış görme" yerine insan mekân ilişkisinin tarihsel doğasına daha uygun olan "çevrel görmeyi" tekrar gündeme getirmenin kavramsal referansları 20. yüzyılın son çeyreğinde olgunlaşan çevre estetiği kuramında bulunabilmektedir. Dini mekânların Berleant'in deyimi ile yüklenim estetiği kaygısı taşıyarak tasarlanması, mekânın sinestetik deneyim ve "çevrel görme" temelinde kurgulanması ve bu yollar ile mimari tasarım bağlamında özgün estetik değerlerin üretimi 20. yüzyıl Türkiye mimarlık literatürüne kabul edilen yapılar için değerlendirme ölçütü olarak alındığında bu yapıların biçimsel ve tipolojik kategorilerin ötesine geçerek mimari niteliği temsil eden çevre estetiği gibi farklı bir kuramsal çerçeve içerisinde yeniden okunması mümkün olabilecektir.

$\mathrm{Bu}$ çalışmaya konu olan Etimesgut ve T.B.M.M. camilerinin de mimari tasarımda çevre estetiği kavramları açısından okunması ile birlikte, bu yapılara hâkim olan mimari tasarım yaklaşımlarında kullanıcının mekânsal deneyimi açısından özgün değerler ortaya konduğu ve tasarımların ortak kavramlar ile açıklanabilecek bir düşünce zemininde temellendikleri görülebilir.

İncelenen yapıların müelliflerinin 20. yüzyıl Türk mimarlı̆̆ındaki önemleri konusunda tereddüt bulunmamakla birlikte başarıları uluslararası düzeyde de tanınmaktadır. Cengiz Bektaş ve Behruz Çinici - Can Çinici "Müslümanların önemli derecede varlığa sahip olduğu dünyanın farklı toplumlarının ihtiyaçları ve özlemlerine başarıyla hitap eden yapı konseptlerini belirlemek ve teşvik etmek" amacıyla "mimarlık, planlama pratikleri, tarihi koruma ve peyzaj mimarlığında yeni kalite standartları ortaya koyan projelere"1977'den itibaren üç yılda bir verilmekte olan Uluslararası Ağa Han Mimarlık Ödüllerini (Url 5) alan Türk mimarlarındandır. Cengiz Bektaş, Antalya - Akdeniz Üniversitesi Olbia Sosyal Tesisleri projesi ile 2001'de, Behruz Çinici ve Can Çinici, bu çalışmaya konu olan TBMM Cami kompleksi ile 1995'de bu ödüllere layık görülmüştür. Ödüller mimarların tasarım düzeylerini belirleyici verilerdir.

Adı geçen mimarların konu edilen cami tasarımları şimdiye kadar, farklı sebepler ile nitelikli mimari eserler olarak 20. yüzyıl Türk mimarlık literatürüne dâhil edilmişler (Url 2; 
Hasol 2017) fakat ortak bir kavramsal çerçeve bağlamında tartışılmamışlardır. Bunun sebebi genelde yapılara cami mimarisine hâkim olan biçimsel tartışmalar bakımından yaklaşılmış olmasıdır. Oysa yapılar çevre estetiği kuramı açısından yeniden okunduğunda ortak bir tartışma zemini oluşturmak mümkündür. Her iki yapının tasarımında da, tarihsel formların sorgusuz kabulünden kaynaklanan biçimsel şartlanmaların ağır bastı ̆̆ı, işverenlerin dikte ettiği kalıpların hâkim olduğu, tasarımda derinlikli entelektüel sorgulamalara fazlaca rastlanılmayan cami programına eleştirel bir yaklaşım söz konusudur. İki örnekte de toplumsal konvansiyonlara karşı çıkılarak kullanıcının mekândaki estetik deneyimi ve insan ölçeğinden algıları öncelenmiştir.

Çevre estetiği kuramı temelinde yapılan bu yeniden okuma önerisi yapıların mimarlık tarihindeki konumlarını belirlemek için biçimsel ve tipolojik sınıflandırmalara (Akbulut \& Eraslan 2017) göre daha uygun olacaktır çünkü müellifler tasarımda biçimi amaçtan çok araç olarak gören ve tasarımda kavramsal temellere, dolayısıyla sorgulayıcı - eleştirel düşünceye önem veren mimarlardır. Bu iddiadan hareketle, yukarıda tanımlanan değerlendirme zemini bağlamında yapıların incelemesi aşağıdaki şekilde yapılabilir.

Cengiz Bektaş, Etimesgut Camii tasarımında tarihsel referanslı kubbe ve minare biçimlerini kullanmamayı tercih etmiştir. Buna karşın minareyi hatırlatan dikey kütle üzerindeki hilal şeklinde bir âlem yorumu yapılmış (Fig. 3), bu kütlenin içerisindeki merdiven ile üst kattaki kadınlar bölümüne bağlantı sağlanmıştır (Url 2). Üst örtü kubbe yerine betonarme kaset döşeme kullanılarak inşa edilmiştir. Bu tercih, kubbenin kaçınılmaz teknik gereksinim olmaktan çıktığı bir dönemde yapısal öğelerin çağdaş tektonik gerekçelere dayanması gerektiği yönündeki düşüncenin yansımasıdır. Bektaş, kendisinden başlangıçta 1.000 kişiye hizmet edebilecek bir cami tasarlanması istendiğini fakat bu sayıyı abartılı bulduğunu, yetkililer ile görüşmeleri sonucunda 300 sayısı üzerinde mutabık kalındığını kaydeder (Url 2). Bektaş'ın tasarım süreci konusunda verdiği bilgiler büyük ölçeğin ve tarihsel biçim referanslarının dikte edildiği bir işlevsel programda sorgulayıcı ve eleştirel bir tavır sergilediğini, ihtiyaçlar ve eldeki fiziki imkânlar çerçevesinde rasyonel düşünceye başvurarak çözüme ulaşmaya çabaladığını ve sürecin paydaşlarını ikna etmeyi başardığını göstermektedir. Bu tasarım yaklaşımının hedefi bir kavram ile ifade edilmeye çalış1lsaydı "mütevazılık" uygun düşebilirdi. Bektaş, uygulamada profesyonel olmayan erlerden oluşan iş gücünden istifade edildiğini ve erlere inşaat işçiliğine ilişkin eğitim verdiğini anlatır (Url 2).

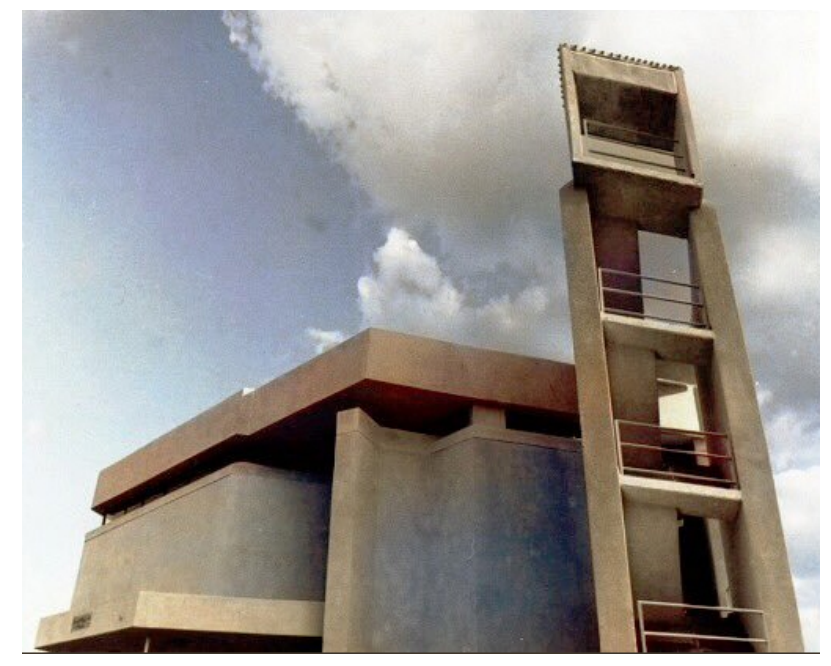

Fig. 3. T.B.M.M. Cami Minaresi (Url 6) 
Etimesgut Camii'nin tasarımında yalın üst örtü ve mekânsal sınırlayıcılar kullanılarak bütüncül bir ibadet mekânı tanımlamıştır. Mimar, plan çizimlerinde görülen baklava formundaki ızgara sistemini (Fig. 4) bir araç olarak kullandığını, bu ızgaranın dikte ettiği biçimler ile sınırlı kalmadığını, iç mekânın genel formunu belirlerken işlevi düşünerek esnek davranabildiğini ifade etmektedir (Bektaş ile kişisel görüşme 2019). Bektaş'in bu bağlamda sözünü ettiği "işlev" konusunda ortaya koyduğu özgün yorum yapıyı çevre estetiği kuramı açısından değerlendirmeyi mümkün hale getirmektedir. Elde edilen mekânsal etki bu noktada modernist mimarlık çerçevesiyle sınırlı mekanik bir işlevselciliğe (Colquhoun 1990) işaret edilmediğini göstermektedir.

İbadet işlevi iklimsel konfor ihtiyaçlarının sağlanmasının ötesinde, ibadetin tanımlanmış prosedürleri uyarınca kullanıcının mekâna duyusal katılımı ile uhrevi duygular hissetmesini de gerektirir. Farklı dinlerin ibadet mekânlarında ve tarihsel cami örneklerde olduğu gibi bu tür bir algıya ulaşılması için tasarım öğeleri ile 1şık gölge kontrastları elde edilmiştir. İç mekânı tarif eden sınırlayıcı mimari öğeler, kullanıcıyı dıș dünyadan ve doğal 1şıktan tecrit etmemiş, farklı namaz vakitlerindeki gün 1şığı değerlerinin ve yönlerinin değişimi iç mekâna yansıtılarak kullanıcının dışarısı ile duyusal irtibatı sağlanmıştır. Işık - gölge etkileri uhrevi hissiyatları harekete
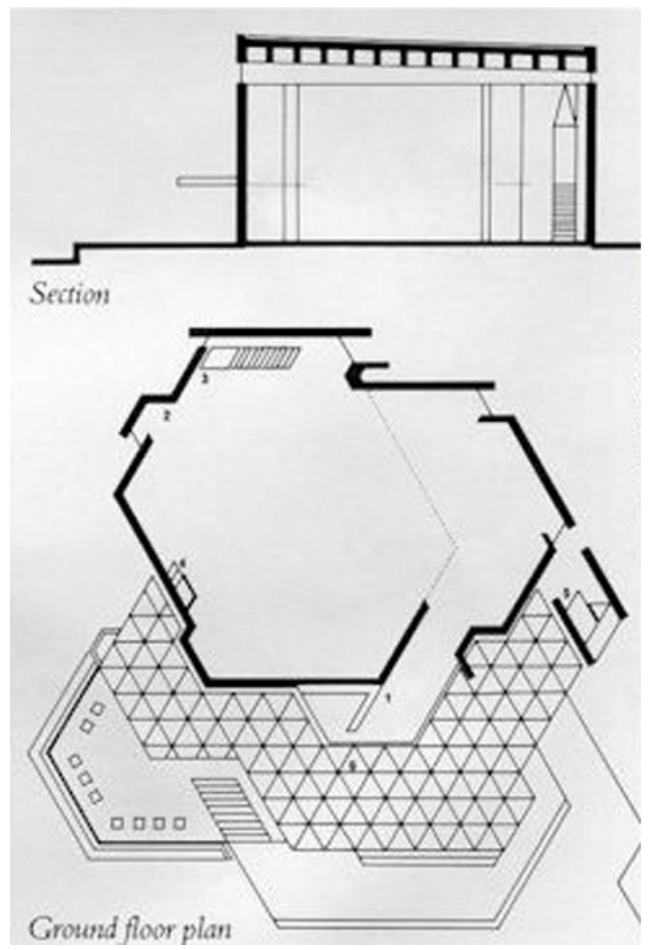

Fig. 4. Etimesgut Cami Planı ve Kesiti (Url 7) geçiren bir atmosferin oluşumuna katkı sağlamaktadır. Kıble duvarında yer alan mihrap ve yanı başında konumlanan minber, mimarın duvarda oluşturduğu yarıklardan sağladığı gün 1şı̆̆ ile kutsallık betimlemesini pekiştiren öğeler olarak karşımıza çıkar (Fig. 5). Işık-gölge etkileri ile günün her saati farklı algılanan objelere dönüşen öğeler, kullanıcısı için farklı duyusal deneyim potansiyelleri sağlanan mekânda estetik değer kazanırlar.

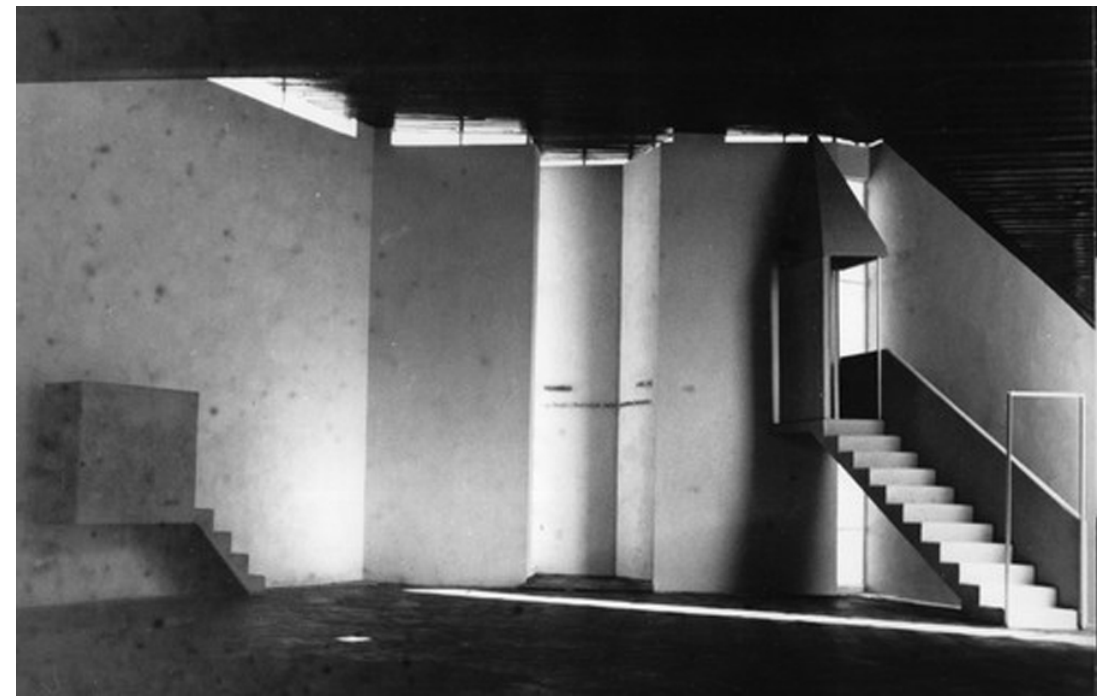

Fig. 5. Etimesgut Cami Mihrap ve Minberi (Url 1) 
Estetik deneyim açısından önemli bir öğe haline gelen kıble duvarı Behruz Çinici ve Can Çinici'nin TBMM Cami kompleksi tasarımında da öne çıkan yorumlardan birine sahne olmuştur. Caminin iç mekân ölçeğinde kurucu öğeleri arasında yer alan kıble duvarının cennet imgesi çerçevesinde yorumlanışı ile ilgili olarak Mimar Sinan'ın tasarladığı Sokullu Mehmet Paşa Camii (1571-1572) örnek gösterilir. Erzen, kıble duvarını 'ş̧ılk oyunlarıyla işlenmiş bir perde' olarak yorumlar ve kullanıcısına işık ile değişen mekân deneyimi sunan bir mimari yorum olarak çevre estetiği kuramı ile ilişsilendirir (Erzen akt. Özel 2013). TBMM Cami Kompleksi kıble duvarının cennet imgesine dönüştürülerek yorumlandığı çağdaş cami tasarımına örnektir. Camide, kıble duvarı tamamen saydamlaştırılmış, kot farkı ile oluşturulan gömük bahçedeki peyzaj tasarımı ile iç mekân arasında kuvvetli bir görsel bağ kurulmuştur (Fig. 6). Cennet imgesinin bir parçası olarak bilinen su öğesi de hem görsel hem de işitsel boyutları ile peyzaj tasar1mında yerini almaktadır. Bu mekânsal kurgu kullaniciya duyusal deneyim potansiyelleri sunarak zih-

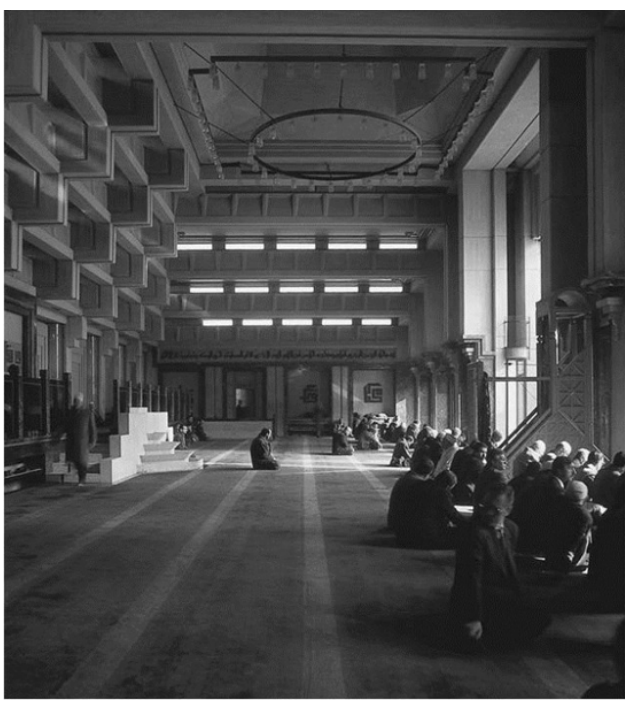

Fig. 6. T.B.M.M. Cami Saydamlaştırılmış Kıble Duvarı ve İç Mekân (Url 8) ninde oluşturacağı bir cennet deneyimine kaynaklık etmektedir. Tunalı'nın vurguladığı gibi geleneksel simgesel öğelerin tekrarından kaçınan bir tasarım anlayışı ile biçimlenen mekân "modern mimarinin yoksullaştırdığı biçimlere karşı mesafe alarak, insanın duygu ve düşüncelerine öncelik tanıyan bir mimari dil geliştirmiştir” (Tunalı 2012).

Avlu, Osmanlı kent yaşamında toplumsal yaşamın merkezinde yer alan cami için önemli bir öğe iken sözü edilen anlamı günümüzde devam etmemektedir. Ancak avlu, modern dünyada dünyevi işlerin gerçekleştiği kent yaşamından uhrevi bir mekân olan ibadet mekânına geçiş için ara mekân olarak değerlendirilebilir ve bu bağlamda estetik deneyim açısından yeniden ele alınabilir. Caminin iç mekânına kutsal olana yapılan yolculukta kazanılan deneyimini şekillendirecek olan avludur. Avluyu besleyen dış mekân öğeleri musalla ve şadırvan, daha doğru ifadesi ile abdesthane, avlunun işlevsel kullanımını tanımlar. Ara mekân olarak tanımlanan avluda yer alan şadırvanda abdest alınarak beden temizlenir ve camiye girmek, ibadet etmek için gerekli fiziksel şartlar sağlanmış olur (Erzen 2017). Avlu estetik olarak duyusal ara mekân olma halini, yüklendiği işlevsellik ve fiziksel gerçeklik ile de devam ettirir. Avlunun devamında yarı açık mekân olarak karşımıza çıkan son cemaat yeri, yapıyı insan ölçeğine indirmesi ile estetik değer kazanır. TBMM Cami arkadlardan oluşan son cemaat yeri ile üçgen geometrili avluya (Fig. 7) açılarak kademeli alçalışını sürdürür ve insan ölçeğine duyarlı bir giriş cephesine kavuşur (Fig. 8).

Örtü sistemi, iç mekânda oluşturulan uhrevi atmosfere katkısı ve yüklendiği anlamlar dolayısıyla çevre estetiği çerçevesinde değerlendirilebilir. Işık niteliğinin çeşitlenmesine zemin hazırlayan örtü sistemi, 1şık-gölge oyunlarının yaşandığı zengin 1şık kalitesine sahip bir iç mekânın kurulmasını sağlar. Mimar Sinan'ın örtü sistemi olarak kullandığı kubbenin kasnağındaki çok sayıda pencere ile homojen ve zengin bir şekilde ışıklandırılan orta mekân, gözün 1şıkla birlikte yükselmesine ve kubbeyi algılamasına zemin hazırlamıştır (Erzen 2017). TBMM Camii, ibadet mekânının çağdaş yorumlarında örtü sisteminin doğal 1şıkla kutsallığının pekiştirildiği, iç mekânın çevre ile ilişkisinin kurulduğu bir örnektir. Kademeli bir betonarme örtüye sahip olan cami (Fig 9) doğal 1şığın süzülmesine imkân sağladığı açıklıkları ile kullanıcısına değişen 1şık miktarı ile zenginleşen bir iç mekân deneyimini yaşatır. 

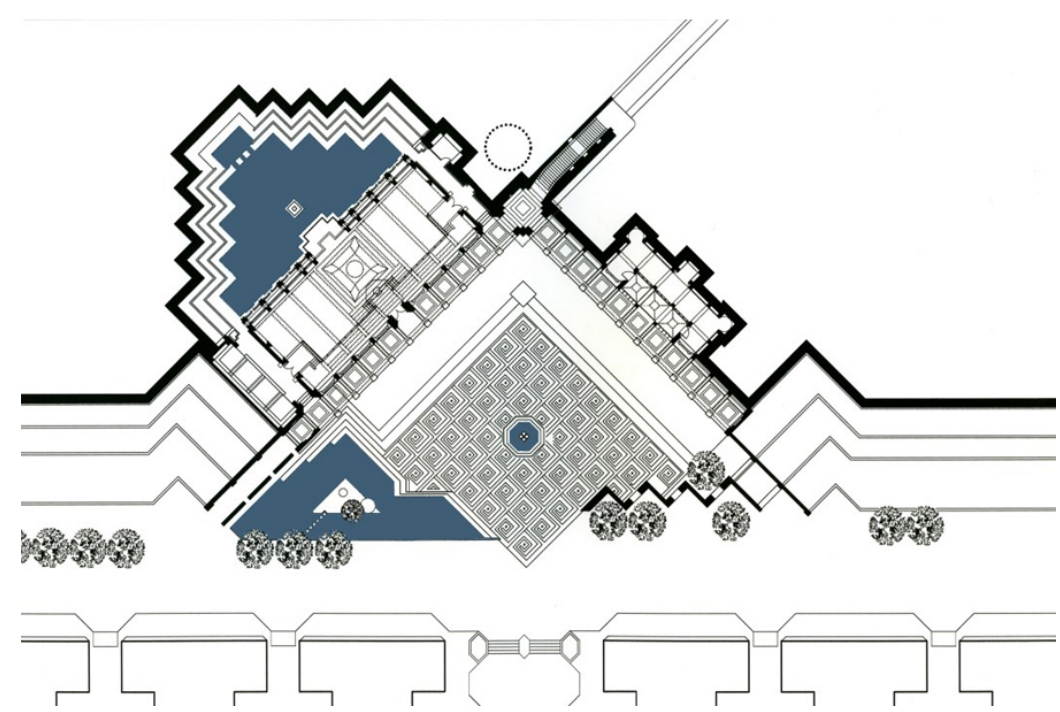

Fig. 7. TBMM Cami Planı (Url 9)

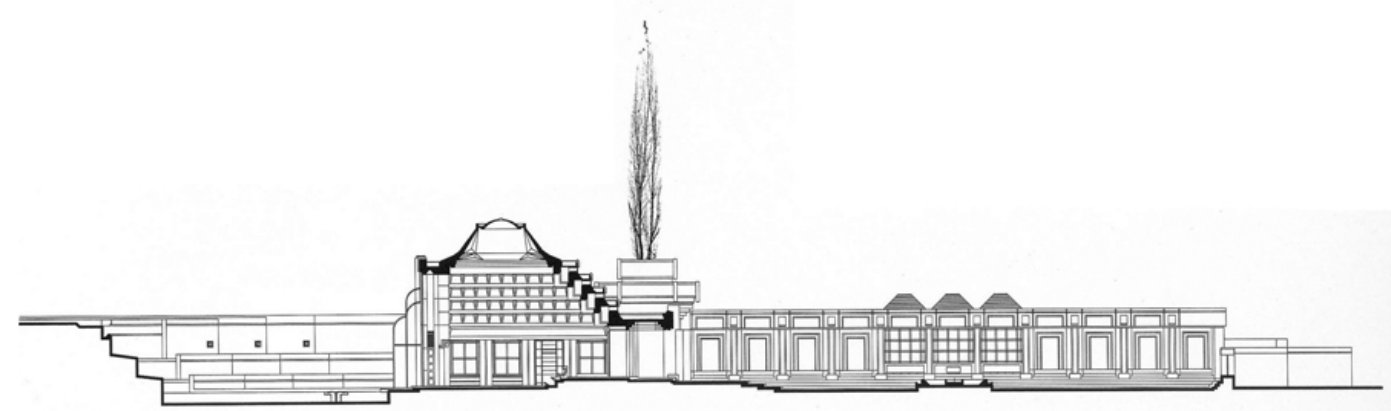

Fig. 8. TBMM Cami Kesiti, Kademelenerek İnsan Ölçeğine Yaklaşan Son Cemaat Yeri (Url 10)

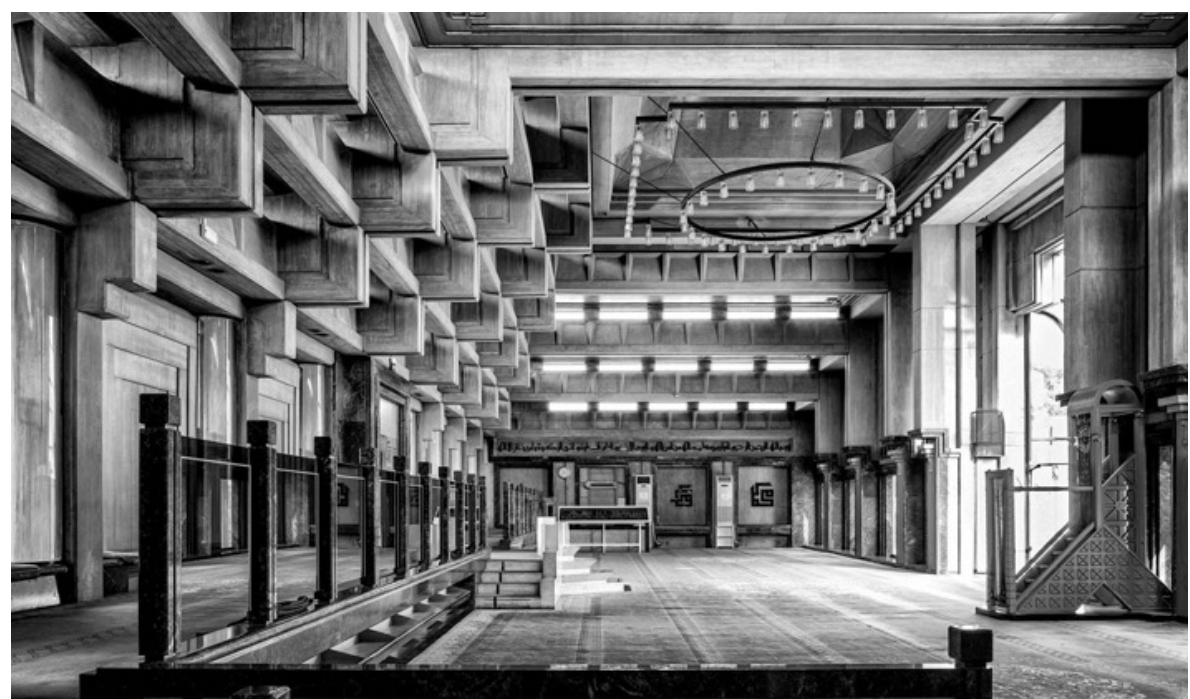

Fig. 9. TBMM Cami İç Mekanı (Url 11) 


\section{Sonuç}

20. yüzyıl Türk mimarlık tarihi içerisinde özgün tasarım yaklaşımları ve nitelikli sonuç ürünleri ile öne çıkan mimarların cami programına getirdikleri yorumları çevre estetiği kuramı bağlamında yeniden okumayı deneyen bu çalışma, seçilen iki örnek arasında şimdiye kadar fazla vurgulanmayan ortak bir tasarım duyarlığını tartışmıştır. Bu okuma birbirinden farklı bağlamlarda geliştirilmiş ve farklı biçimsel sonuçlara ulaşmış tasarım yaklaşımlarının çevre estetiği kavramları açısından ortak bir zemine oturabildiğini göstermektedir. Detaylı açıklamalar ile ortaya konan bu ortak zemin aşağıdaki şekilde özetlenebilir.

Her iki tasarımda da biçimlerin kendi başlarına ideal çözümler ve amaçlar olarak görülmesinden kaçınılmış, aksine biçimler tasarım düşüncesinin hedeflerine ulaşmak için araçlar olarak yorumlanmıştır. Bu yorumlamaya uygun olarak zaman üstü değere sahip olduğu düşünülen herhangi bir tarihsel biçimin "gösterge" değerine indirgenmek suretiyle kullanılmadığı görülmektedir. Bu tasarım kararı çevre estetiği kavramları açısından değerlendirildiğinde "seyir estetiği” anlayışına bir karşı çıkış olarak da okunabilir.

Çevre estetiği kuramının kabul ettiği kapsayıcılığı ile "estetik", iki örnek için de cami tasarımında nitelik sorununun tartışılması açısından uygun bir anahtar sözcük olarak ortaya çıkmaktadır. Etimolojik kökenine uygun olarak duyusallık ve duyulur algının bilimi olarak görülen estetik, bu örneklerdeki tasarım kararlarında da izlenebileceği gibi, mimarlık ile yüzeysel açıklamaların ötesine geçebilen derinlikli ilişkiler kurmaktadır. İncelenen yapıların ortak özelliği duyusal deneyime sahne olan mimarlığın daima estetiğin konusu olduğuna dair olarak tasarımcıların geliştirdikleri farkındalıktır. Tasarımcıların bu ortak farkındalığa dayanan bilinçli tercihleri mekânsal nitelikleri olumlu yönde etkilemiştir. Sorgulanmadan idealize edilen ve kendi içinde amaç olarak görülen biçimler yerine, mekânı deneyimleyen kullanıcının duyusal farkındalıklarına hitap etmek, bir başka deyiş ile "yüklenim estetiği”" için potansiyeller sunmak öncelik olmuştur. Böylece kullanıcının mekâna duyusal ve bedensel katılımı ile hem kendi varoluşunu hem de katılım sağladığı ibadet mekânını anlamlandırması için imkânlar oluşturulmuştur. Mekânsal deneyim olanakları ile kullanıcının algı ve düşünce dünyasının zenginleştirilmesine yönelik bu çaba bir ibadet yapısının işlevsel gereklilikleri açısından da önemlidir. Tasarım nitelikleri çevre estetiği açısından yeniden okunan yapılarda mimarlık pratiği ile çevre estetiğinin konusu olan duyarlıkların tasarım niteliğini olumlu yönde etkileyen doğrultuda örtüştükleri görülmektedir. 


\section{KAYNAKÇA}

Akbulut N. \& Eraslan A. (2017). "Türkiye'de Çağdaş Cami Mimarisi Tasarımında Yenilikçi Yaklaşımlar". İstanbul Aydın Üniversitesi Dergisi 35 (2017) 33-59.

Aydınlı S. (2002) “Estetik: Öznel Bir Beğeni mi, yoksa Nesne/Çevresel Değerler Temsili mi?”. Eds A. Şentürer, Ş. Ural \& F. U. Sönmez, Etik - Estetik (2002) 146-155. İstanbul

Bektaş C. (1973). “Bir Cami, Etimesgut”. Arkitekt 351 (1973-03) 124-125.

Berleant A. (1997). Living in the Landscape: Toward an Aesthetics of Environment. Kansas 1997.

Berleant A. (2007). "Çevre Estetiği Kuramı”. Ed. P. Yoncacı, Sanat ve Çevre (2007) 23-32. Ankara.

Bozkurt N. (1995). Sanat ve Estetik Kuramları. İstanbul 1995.

Colquhoun A. (1990). Mimari Eleştiri Yazıları. Çev. A. Cengizkan. Ankara 1990.

Erzen J. (2006). Çevre Estetiği. Ankara 2006.

Erzen J. (2017). Ü̧̧ Habitus-Yeryüzü, Kent, Yapı. İstanbul 2017.

Eyüpgiller K. K. (2006). “Türkiye’de 20. Yüzyıl Cami Mimarisi”. Mimarlık 331 (2006) 20-27.

Frampton K. (1983). "Towards a Critical Regionalism: Sixpointsfor an Architecture of Resistance”. Ed. P. Townsend, The Anti-Aesthetic, Essays on Post-Modern Culture (1983) 16-30. Washington.

Güzer A. (2009). "Modernizmin Gelenekle Uzlaşma Çabası olarak Cami Mimarlığı". Mimarlık 348 (2009) 21-23.

Hasol D. (2017). 20. Yüzyıl Türkiye Mimarlığı. İstanbul 2017.

Huisman D. (1992). Estetik. Çev. C. Muhtaroğlu. İstanbul 1992.

Özel M. K. (2013). "İslam Tapınma Yapısını Kuran Öğelerin Ardışık Zamanlı Ontolojik Analizi”. 1.Ulusal Cami Mimarisi Sempozyumu Bildirileri (2-5 Ekim 2012) 231-236.

Kavas K. R. (2015). "Environmental Anesthesia and False Vernacular Architecture: The Case Study of the Western Taurus Mountains”. Adalya XVIII (2015) 325-330.

Kuban D. (2013). “Açılış Konuşması”. 1.Ulusal Cami Mimarisi Sempozyumu Bildirileri (2-5 Ekim 2012) (2013) 24-27

Norberg-Schulz C. (1975) Meaning in Western Architecture. New York 1975.

Norberg-Schulz C. (1980) Genius Loci: Towards a Phenomenology of Architecture. New York 1980.

Pallasmaa J. (2011). Tenin Gözleri. Çev. A. U. K1lıç. İstanbul 2011.

Sharr A. (2013). Mimarlar için Heidegger. Çev. V. Atmaca. İstanbul 2013.

Tunalı İ. (2003). Estetik. İstanbul 2003.

Tunalı İ. (2012). Tasarım Felsefesi. İstanbul 2012.

\section{İnternet Kaynakları}

Url 1, https://www.dw.com/tr/almanlar\%C4\%B1n-cami-merak\%C4\%B1/a-15859078 Erişim: 21 Ekim 2019

Url 2, http://www.mimarizm.com/makale/etimesgut-cami-cengiz-bektas_113496 Erişim: 14 Haziran 2019

Url 3, http://cinicimimarlik.com/wp-content/uploads/2015/01/032-1.jpg Erişim Tarihi: 14 Haziran 2019

Url 4, https://plato.stanford.edu/entries/environmental-aesthetics/ Erişim Tarihi: 20 Ekim 2019

Url 5, https://www.akdn.org/architecture Erişim Tarihi: 20 Ekim 2019

Url 6, https://twitter.com/ankaracimbizi/status/940199275639857152 Erişim Tarihi: 21 Ekim 2019

Url 7, https://camigor.tumblr.com/post/11273556622/etimesgut-camisi-askerde-iken-1964te-cengiz

Erişim Tarihi: 21 Ekim 2019

Url 8, http://cinicimimarlik.com/wp-content/uploads/2015/01/032-7.jpg Erişim Tarihi: 21 Ekim 2019

Url 9, http://cinicimimarlik.com/wp-content/uploads/2015/01/032-16.jpg Erişim Tarihi: 21 Ekim 2019

Url 10, http://cinicimimarlik.com/wp-content/uploads/2015/01/032-15.jpg, Erişim Tarihi: 12 Mayıs 2019

Url 11, http://www.arkitera.com/soylesi/907/ugur-tanyeli-ile-soylesi Erişim Tarihi: 12 Mayıs 2019

\section{Görüşme/Sohbet}

Cengiz Bektaş ile kişisel görüşme. Antalya, Mart 2019. 
